Article

\title{
The Impacts of Vineyard Afforestation on Soil Properties, Water Repellency and Near-Saturated Infiltration in the Little Carpathians Mountains
}

\author{
Andrej Hrabovský ${ }^{1}$, Pavel Dlapa ${ }^{1, *}$, Artemi Cerdà ${ }^{2}(D)$ and Jozef Kollár ${ }^{3}$ \\ 1 Department of Soil Science, Faculty of Natural Sciences, Comenius University, Mlynská Dolina, \\ Ilkovičova 6, 84215 Bratislava, Slovakia; andrej.hrabovsky@uniba.sk \\ 2 Soil Erosion and Degradation Research Group, Department of Geography, Valencia University, \\ Blasco Ibàñez 28, 46010 Valencia, Spain; artemio.cerda@uv.es \\ 3 Institute of Landscape Ecology SAS, Štefánikova 3, 81499 Bratislava, Slovakia; j.kollar@savba.sk \\ * Correspondence: pavel.dlapa@uniba.sk; Tel.: +421-2-9014-9574
}

Received: 9 August 2020; Accepted: 11 September 2020; Published: 12 September 2020

\begin{abstract}
Vineyards are a 7000-year-old land-use tradition and both management and abandonment have result in altered soil properties. These have a great effect on water resources and soil services, and this inspired our investigation into the effects of land-use and land-use change on soils in the Modra wine-growing region in South-western Slovakia. Ten topsoil samples were taken at each of the seven research sites $(n=70)$ on granite parent material in cultivated and afforested vineyards and original forest soils. Laboratory analyses included determination of soil texture, organic carbon content, soil $\mathrm{pH}$, and water repellency. This was supplemented by infiltration measurements under near-saturated conditions at the vineyard and afforested study sites. Studied soils have a low clay content and a high proportion of sand. The vineyard soils have significantly higher $\mathrm{pH}$ than the forest and afforested soils because the naturally acidic soils have been limed. The forest and afforested soils have similar properties, with higher organic carbon content. This makes them strongly to extremely water repellent and contrasts sharply with the wettability of cultivated vineyard soils. One afforested site, however, was less acidic and therefore was considered transitional between forest and vineyard soils. Our infiltration measurements established the influence of soil water repellency on the infiltration process, and our results highlighted that the infiltration rate in the vineyard soils was significantly higher than in afforested soils. The infiltration rate also gradually increased over time in afforested soils due to decreasing water repellency. Physically impossible negative sorptivity values in afforested soils were noted because of changes in water repellency during the infiltration process. Finally, we conclude that soil afforestation results in increased soil water repellency and a subsequent reduction in the infiltration rate at the matrix scale.
\end{abstract}

Keywords: soils; land-use; vineyards; afforestation; water repellency; infiltration

\section{Introduction}

Soil has a crucial influence on matter and energy cycles, and knowledge of these cycles is most important in understanding the Earth's surface geography. Rodrigo-Comino et al. [1] highlighted the interconnection between different geographical spheres and Keesstra et al. [2] reported that soil systems provide ecosystem services and determine the Earth's hydrological, erosional and biogeochemical cycles.

Most recently, Visser et al. [3] emphasized the importance of soil in sustainable development and in implementing strategies which achieve land degradation neutrality. The United Nations has also stressed that soils are relevant in achieving its Sustainable Goals initiative, and soil scientists have 
accepted the associated challenges. Scientific work is now influencing land managers, politicians, practitioners, end-users, and other scientific disciplines in acknowledging that soils are a key component of the Earth's function and thus are crucial for human sustainability [4].

The fate of soil water and carbon is most important because of their effect on the water cycle and climate change $[5,6]$. Current research shows that relevant soil processes are fundamentally influenced by land-use and land management because soils constitute the first earth system affected by humans in agriculture, grazing, mining, and infrastructure development [7-9]. Land-use is also very dynamic due to continuous global activity and technological innovation, and resultant farming, grazing, transport, industry, tourism, mining, and other economic activities affect the Earth's surface [10-12].

There is also frequent deforestation and transformation of forests into agricultural land in the tropics and subtropics [13-17]. In contrast, developed economies often abandon cultivated agricultural land for settlements and industry or return it to grassland and forest [18-20]. This abandonment results in altered soil properties on the long and medium-term scale [21,22], and it inevitably changes soil-water interaction. This applies especially to infiltration rates [23-25], reduced water runoff and soil erosion $[25,26]$.

The transformation of agricultural land into forest land or grassland continues in many parts of Europe. This is particularly noticeable in transformed economies in Eastern Europe, where existing agricultural land-use in many places became increasingly unprofitable in the early 1990s, following the demise of cooperative farming. This process proved disastrous for water runoff, solute output [27], and mountain management in Mediterranean Europe [28].

This trend is especially important in areas where soils are less fertile and more susceptible to degradation from compaction or erosion and there is accompanying low agricultural profitability and rural emigration $[29,30]$. In addition, bare soils without vegetation cover are highly susceptible to increased compaction, surface runoff, and erosion [31]. The arable soils in these regions can therefore be converted into grasslands, subjected to planned afforestation, or left to natural re-vegetation [32-34]. All these changes result in altered runoff discharge, sediment availability, and landforms [35-37].

At the turn of the 19th and 20th centuries, many pests ravaged vineyards throughout Europe. For example, the Phylloxera vastatrix, Plasmopara viticola, and Uncinula necator species altered vineyard use in Slovak wine-growing regions. Resultant dramatic changes in land-use are also linked to the economic and social conditions in particular countries and their climate conditions. Thus, the pest attacks and the social changes in Slovakia from 1949-1953 changed many vineyards into other land-uses. It has been well established that land-use changes have a great impact on soil properties and processes [38-40], and it is therefore necessary to assess these effects on individual soils.

One of the most significant consequences of changing arable land to pasture or forest is increased soil organic matter content [41-47]. The soil organic matter is primarily responsible for changes in soil wettability, and many authors have established a strong correlation between soil organic matter content and soil water repellency [48-51]. These water repellent soils have a soil-water contact angle $\varphi>90^{\circ}$. In addition, the impact of water repellency on soil processes is well-described in the literature [52-54], because it typically decreases infiltration rate $[55,56]$ and then influences preferential flow $[57,58]$.

This paper investigates the impact of afforestation and vineyard cultivation on soil properties. Soils converted to forests over the last century are compared with those used in vineyards, with special emphasis on the effects of land-use on the soil properties, the susceptibility to water repellency development, and the impacts of agriculture land abandonment.

\section{Materials and Methods}

\subsection{Study Sites}

The study area is situated on the south-eastern slopes of the central part of the Little Carpathians mountain range in the surrounds of the Modra Township in south-western Slovakia. The soils here developed from granitic rocks and they are classified as Haplic Cambisols (Dystric) under 
the International Union of Soil Sciences (IUSS) Working Group World Reference Base (WRB) [59]. The mean annual air temperature is $6^{\circ} \mathrm{C}-8{ }^{\circ} \mathrm{C}$ [60] and the annual precipitation is 600-700 $\mathrm{mm}$ [61]. The original forests have a tree and shrub layer dominated by oak (Quercus petraea agg.) and hornbeam (Carpinus betulus), and a herb layer composed of forest mesophytes. On the other hand, the tree layer in the afforested vineyards is dominated by oak (Quercus petraea agg.) and the herb layer comprises both forest mesophytes and nitrophytes (synanthropic species). The forests on the sites of former vineyards have formed spontaneously over the last 100 years. Finally, the vineyard soils have variable segetal vegetation, traditionally classified in the Veronico-Euphorbion Sissingh ex Passarge 1964 alliance. The sampling sites are listed in Table 1 and a view of the different land-uses is shown in Figure 1.

Table 1. Study site locations and land-use around Modra Township in Western Slovakia.

\begin{tabular}{cccc}
\hline Study Site & Latitude & Longitude & Land-Use \\
\hline F1 & $\mathrm{N} 48^{\circ} 20^{\prime} 36.3^{\prime \prime}$ & $\mathrm{E} 17^{\circ} 17^{\prime} 01.7^{\prime \prime}$ & original forest \\
F2 & $\mathrm{N} 48^{\circ} 20^{\prime} 35.5^{\prime \prime}$ & $\mathrm{E} 17^{\circ} 17^{\prime} 09.2^{\prime \prime}$ & afforested vineyard \\
original forest \\
F3 & $\mathrm{N} 48^{\circ} 19^{\prime} 41.8^{\prime \prime}$ & $\mathrm{E} 17^{\circ} 16^{\prime} 43.7^{\prime \prime}$ & vineyard \\
V1 & $\mathrm{N} 48^{\circ} 20^{\prime} 26.2^{\prime \prime}$ & $\mathrm{E} 17^{\circ} 17^{\prime} 26.3^{\prime \prime}$ & vineyard \\
V2 & $\mathrm{N} 48^{\circ} 18^{\prime} 56.2^{\prime \prime}$ & $\mathrm{E} 17^{\circ} 16^{\prime} 54.1^{\prime \prime}$ & vineyard \\
V3 & $\mathrm{N} 48^{\circ} 18^{\prime} 53.0^{\prime \prime}$ & $\mathrm{E} 17^{\circ} 16^{\prime} 58.3^{\prime \prime}$ & afforested vineyard \\
TF & $\mathrm{N} 48^{\circ} 19^{\prime} 23.1^{\prime \prime}$ & $\mathrm{E} 17^{\circ} 16^{\prime} 50.3^{\prime \prime}$ & r
\end{tabular}
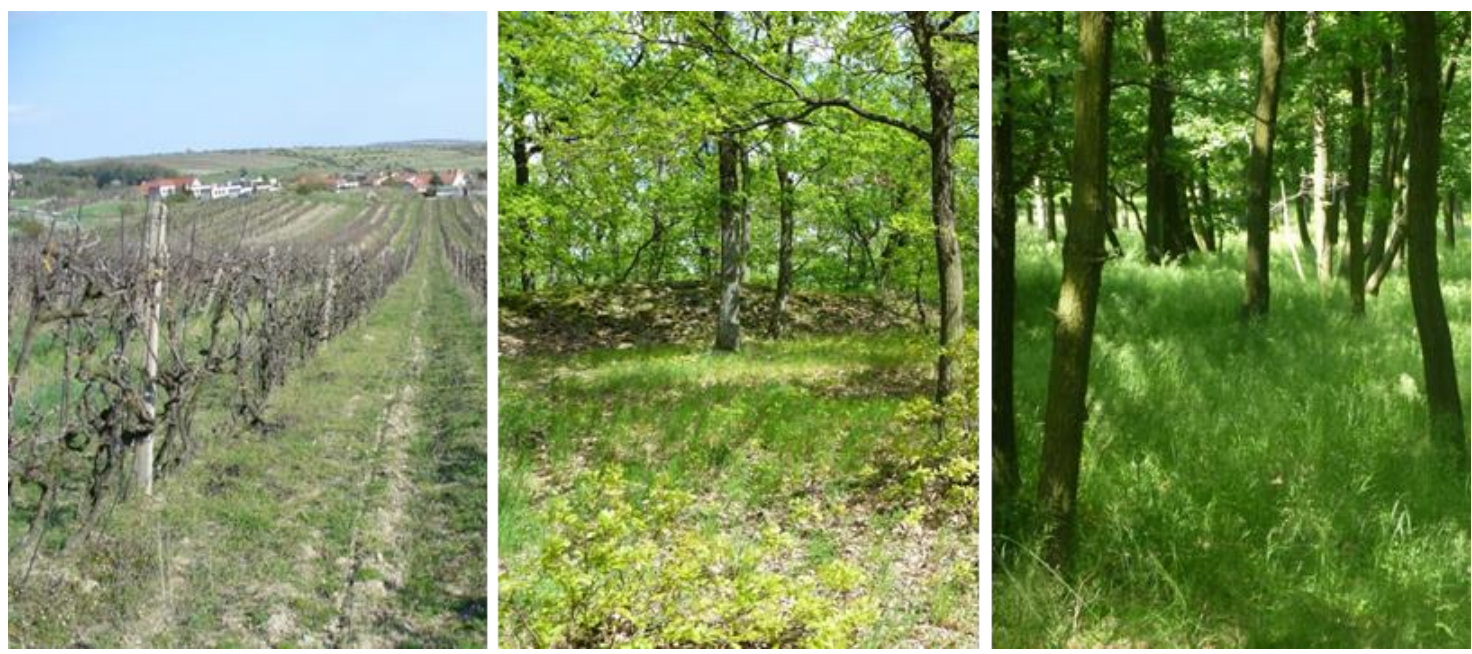

Figure 1. Left to right: the vineyard, afforested, and forest plots.

\subsection{Field and Laboratory Methods}

Ten random soil samples were taken at a depth of $0-10 \mathrm{~cm}$ from $20 \times 20 \mathrm{~m}^{2}$ plots at each study site. Gravel and plant residues were removed before laboratory analysis, and samples were gently ground to pass through a $2-\mathrm{mm}$ sieve. Soil $\mathrm{pH}$ was established at a 1:2.5 soil/distilled water ratio $(w / v)$. Particle size distribution was then determined by measuring the amount of soil particles in suspension after various settling times and the fraction size percentage was determined by the pipette method [62]. Finally, soil organic carbon content was determined by potassium dichromate oxidation [63].

The persistence of water repellency in all samples was estimated by the widely used water drop penetration time test (WDPT) after two-week equilibration at $20^{\circ} \mathrm{C}$ and $50 \%$ relative humidity. The measured WDPT values gave the following soil classifications [54]: wettable soils $(<5 \mathrm{~s})$, slightly water repellent (5-60 s), strongly water repellent (60-600 s), severely water repellent (600-3600 s), and extremely water repellent (>3600 s).

Four replicated infiltration experiments were performed in the vineyard and afforested research sites using a Mini Disk Infiltrometer (Decagon Devices, Inc., Pullman, WA, USA). This was set to 
a $-2 \mathrm{~cm}$ supply pressure-head and filled with water. The time required to infiltrate each $\mathrm{cm}^{3}$ of water was recorded and the cumulative infiltration dependence was determined by regression Equation (1):

$$
I=C_{1} t^{0.5}+C_{2} t
$$

where $I$ is the cumulative infiltration $(\mathrm{cm}), C_{1}$ is the constant corresponding to sorptivity $S\left(\mathrm{~cm} \cdot \mathrm{s}^{-0.5}\right)$, $C_{2}$ is the constant related to unsaturated hydraulic conductivity $\left(\mathrm{cm} \cdot \mathrm{s}^{-1}\right)$, and $t$ is the time (s).

\subsection{Statistical Analysis}

Statistical analysis was performed using the 'LMFIT for Python' package [64]. ANOVA and Tukey tests were used to evaluate differences in soil properties in the study plots and the determination coefficient $\left(r^{2}\right)$ was calculated for regression relationships. The WDPT values were evaluated as log-normal. For all statistical tests, the level of significance was chosen as $p<0.05$.

\section{Results}

\subsection{The Impact of Afforestation on Soil Properties}

Average soil $\mathrm{pH}$ values vary over a wide range and depend on land-use history (Table 2). The strong acidity in forest and afforested soils is a consequence of natural soil-forming processes on granitic parent rock. Soil organic carbon (SOC) gradually accumulates during soil development, with a concurrent soil $\mathrm{pH}$ decrease. Figure 2 highlights a significant indirect relationship between SOC and $\mathrm{pH}$ in sites F1, F2, and F3. In addition, the SOC content is significantly higher and the soil pH is significantly lower in forest and afforested soils than in the vineyard soils.

Table 2. Basic soil properties determined in 10 samples at each study site.

\begin{tabular}{ccccccccccccc}
\hline Study & \multicolumn{2}{c}{ pH } & \multicolumn{3}{c}{ SOC (wt.\%) } & \multicolumn{2}{c}{ Sand (wt.\%) } & \multicolumn{2}{c}{ Silt (wt.\%) } & \multicolumn{2}{c}{ Clay (wt.\%) } & \multicolumn{2}{c}{$\log$ WDPT } \\
\hline Site & Mean & SD & Mean & SD & Mean & SD & Mean & SD & Mean & SD & Mean & SD \\
\hline F1 & 4.05 & 0.10 & 8.61 & 2.35 & 54.1 & 4.0 & 35.0 & 3.1 & 10.9 & 1.6 & 4.13 & 0.18 \\
F2 & 4.58 & 0.17 & 5.92 & 1.86 & 60.6 & 3.6 & 29.6 & 2.9 & 9.5 & 1.0 & 2.72 & 0.99 \\
F3 & 4.33 & 0.14 & 5.72 & 1.73 & 55.8 & 3.8 & 34.6 & 3.1 & 9.6 & 0.9 & 1.92 & 0.98 \\
V1 & 6.04 & 0.20 & 0.56 & 0.16 & 70.6 & 2.0 & 22.8 & 1.5 & 6.7 & 0.6 & 0.00 & 0.00 \\
V2 & 6.95 & 0.61 & 1.83 & 0.50 & 49.9 & 3.2 & 38.9 & 2.4 & 11.3 & 1.1 & 0.00 & 0.00 \\
V3 & 7.52 & 0.16 & 2.03 & 0.14 & 47.1 & 2.5 & 38.2 & 1.0 & 14.7 & 1.9 & 0.00 & 0.00 \\
TF & 5.67 & 0.43 & 7.32 & 1.16 & 63.2 & 2.8 & 30.7 & 2.7 & 6.1 & 0.9 & 1.35 & 0.72 \\
\hline
\end{tabular}

SOC: soil organic carbon content; SD: standard deviation.

The opposite situation occurs in current vineyards. Soil properties there are influenced by the overturning of soil horizons during the vineyard establishment, and the topsoil has very low organic matter content when the humus horizon has been transferred to a greater depth. The topsoil SOC content then gradually increases during cultivation and its $\mathrm{pH}$ increases due to liming. Figure 2 therefore shows a close relationship between soil $\mathrm{pH}$ and SOC content for sites V1, V2, and V3. The liming induces significantly higher $\mathrm{pH}$ than in forest soils and the soil often becomes alkaline (Table 2).

Figure 2 also shows that the TF afforested site samples have specific characteristics. Their chemistry falls in the transition between vineyard and forest soils. Thus, these samples indicate how the chemical properties gradually change following vineyard afforestation and they highlight their gradual acidification. There is an initial recovery of organic matter, that will eventually change the soil water repellency and infiltration rate.

The soil particle size distribution varies widely in the vineyard and forest soils, and the intervals overlap. The sand content dominates the silt content in all soils and the clay content is very low (Table 2). In addition, the V1 re-established vineyard soil has the highest sand content and lowest clay content of all research plots. 


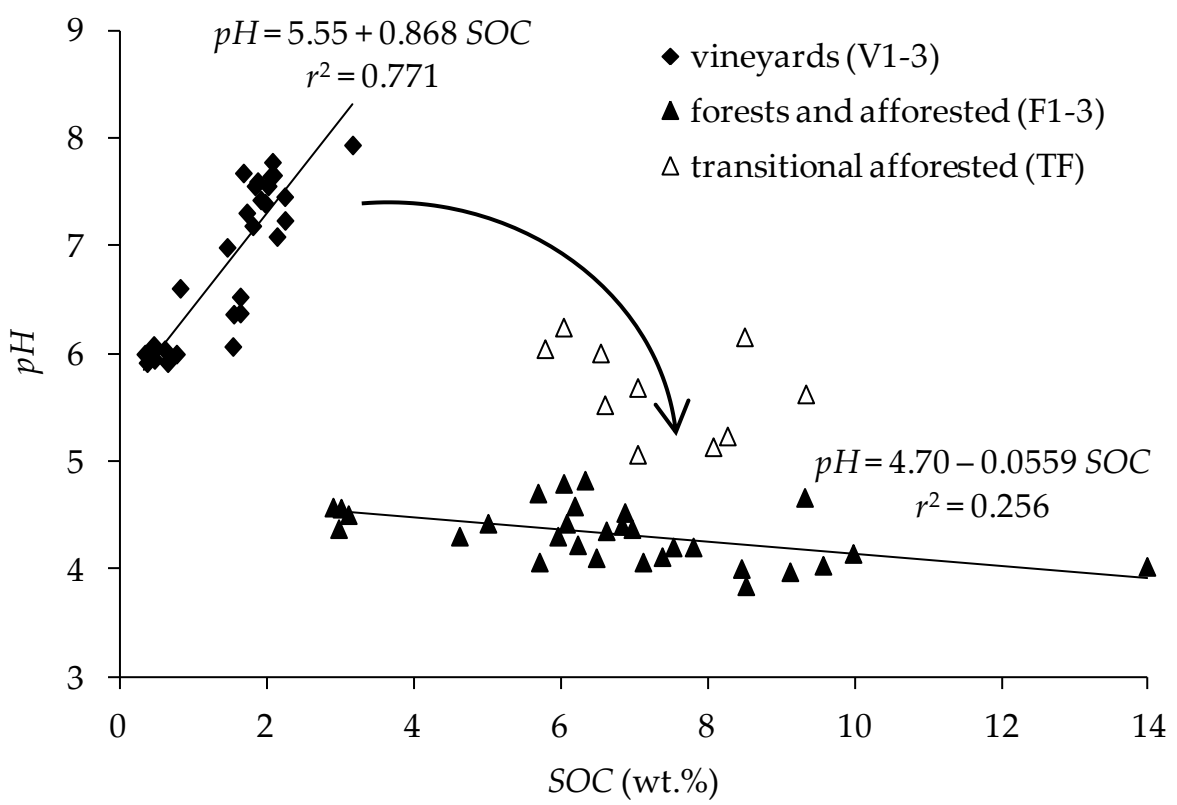

Figure 2. SOC content and soil $\mathrm{pH}$ relationships in samples collected from vineyards, forests, and afforested vineyards.

\subsection{Soil Water Repellency}

The persistence of water repellency, determined as WDPT, primarily depends on SOC content. Vineyard soils have the lowest carbon content, and it is not surprising that the V1, V2, and V3 site soils are all wettable.

The forest and afforested soils have varying degrees of water repellency. Figure 3 shows that repellency severity mainly depends on SOC content. The persistence of water repellency was highest in the F1 forest plot, which has 13,600 s mean WDPT, classified as extremely water repellent. The afforested F2 vineyard plot has strongly water repellent soils, with $530 \mathrm{~s}$ mean WDPT, and the F3 forest plot has $84 \mathrm{~s}$ mean WDPT. The differences between F1, F2, and F3 plots are statistically significant, at $p<0.05$.

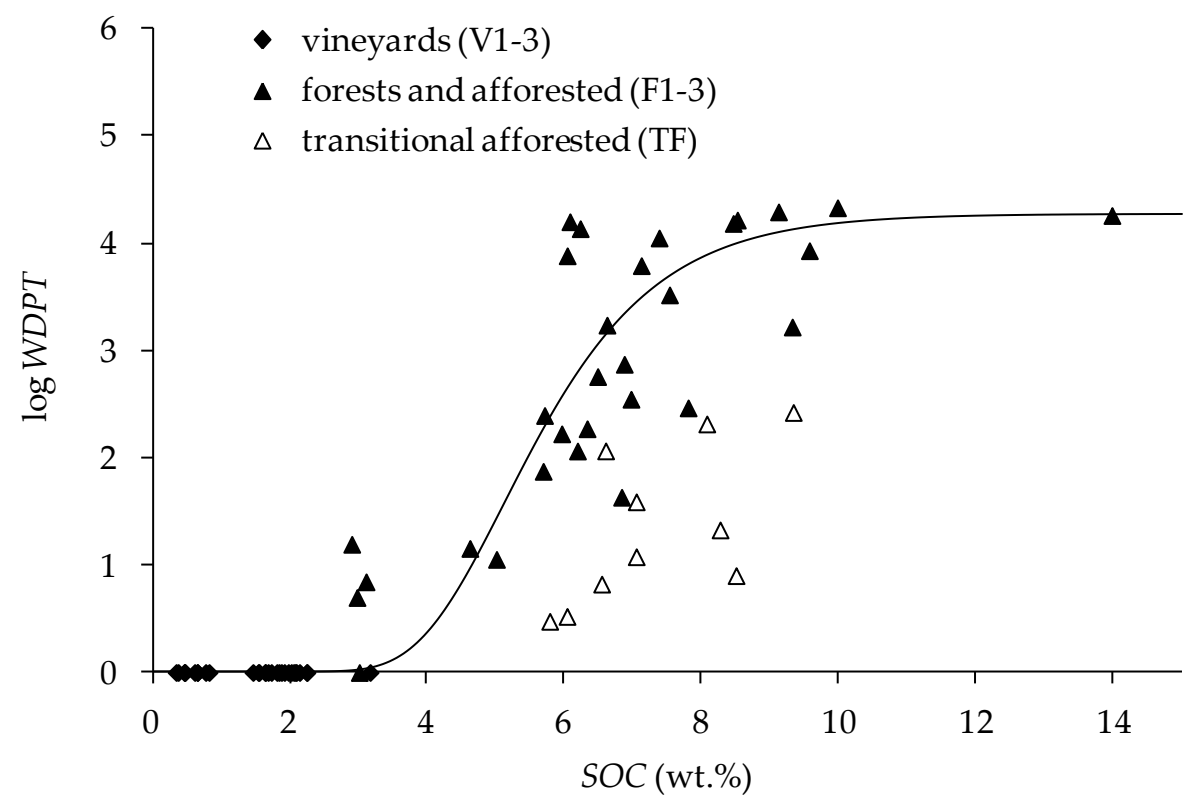

Figure 3. Dependence of persistence of soil water repellency (log water drop penetration time test (WDPT)) on SOC content at the vineyard, forest, and afforested study sites. 
The TF afforested vineyard is in a transient stage between vineyard and forest soil. Although Figure 2 shows that the soil $\mathrm{pH}$ values are higher than other forest and afforested soils, Figure 3 highlights that the WDPT values are lower than those which correspond to SOC content. The lower than expected soil water repellency is attributed to higher soil pH in the TF study plot than at the other forest and afforested sites.

\subsection{Infiltration under Near-Saturated Conditions}

Field measurements established that the persistence of water repellency (WDPT) has major impact on infiltration, and Figure 4 shows the infiltration trends. At the V1 vineyard with WDPT $<1$ s, the infiltration rate was highest at the start because of the capillary force but this rapidly decreased until it stabilized, which corresponded to the action of gravity under near-saturated conditions (at $h=-2 \mathrm{~cm}$ ).

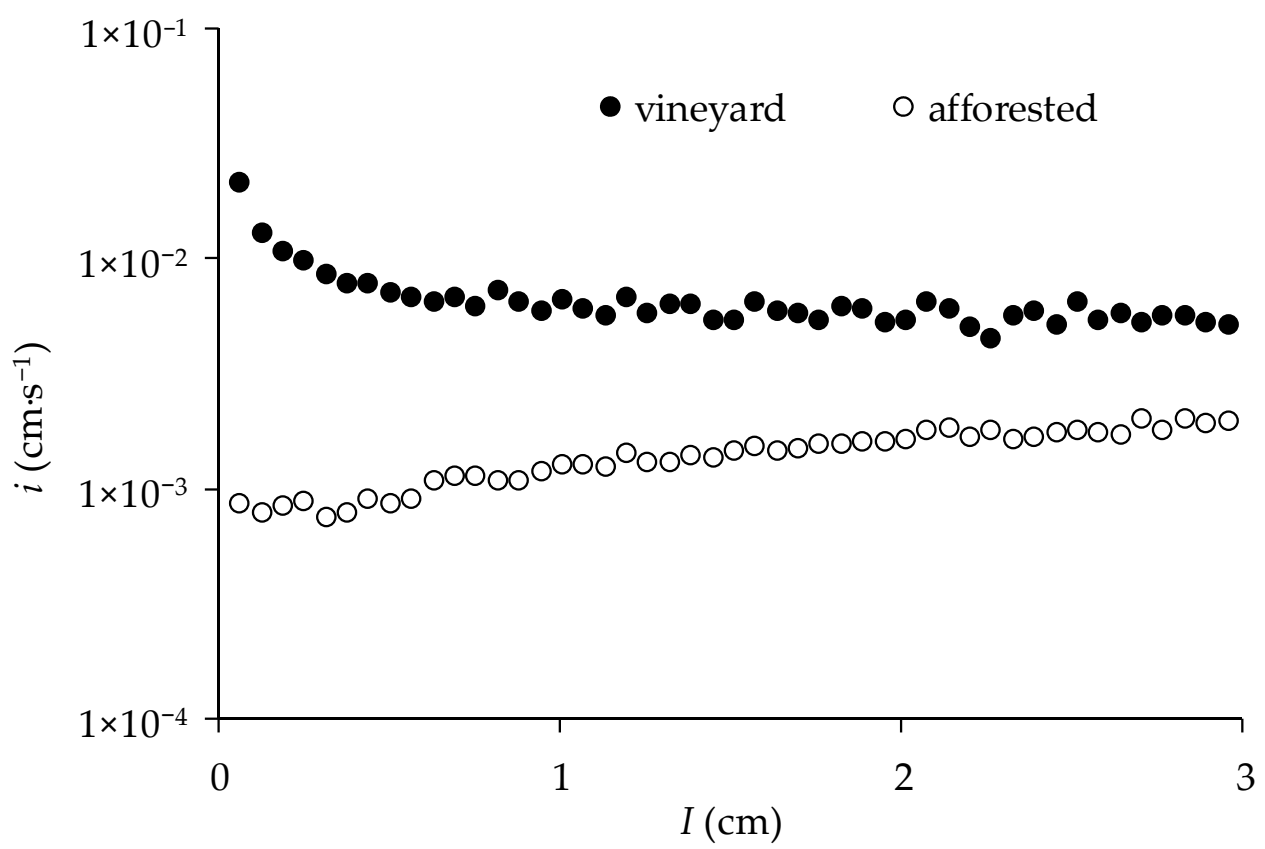

Figure 4. Dependence of infiltration rate (i) on the extent of infiltration $(I)$. The points show the average values of four independent infiltration measurements in the vineyard and afforested research plots.

In contrast, the afforested vineyard TF soils had weak (23 s) mean water repellency, with its lowest infiltration rate at the beginning of the experiment, and this then slowly increased (Figure 4). The infiltration rate was significantly lower than in the vineyard soil. Figure 5 shows the following two trends in the course of infiltration. Cumulative infiltration dependence on time creates a concave curve in the wettable V1 soil and a convex curve in the water repellent TF afforested soil. In addition, the persistence of water repellency was too high to measure the infiltration in the strongly and extremely water repellent soils, at $h=-2 \mathrm{~cm}$.

Equation (1) was fitted to field infiltration data and the regression equations are listed in Figure 6. The $C_{1}$ and $C_{2}$ constants from these equations reveal that the TF forest-site water repellency decreased both parameters more than an order of magnitude compared to the V1 vineyard site. The lower diagram in Figure 6 shows that the $S=C_{1}$ sorptivity had negative values in two instances. Such negative parameter values in Equation (1) are physically impossible and the values suggest that the infiltration course is significantly influenced by changing water repellency, and that infiltration increases when water repellent substances are washed out or removed. 


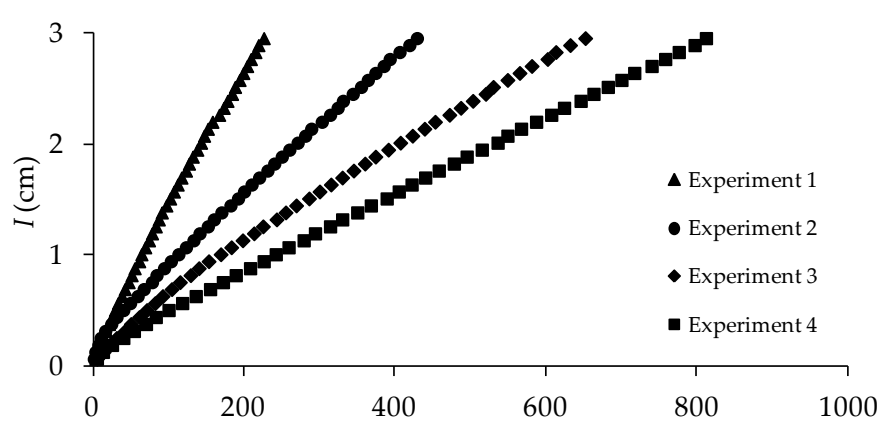

$t$ (s)

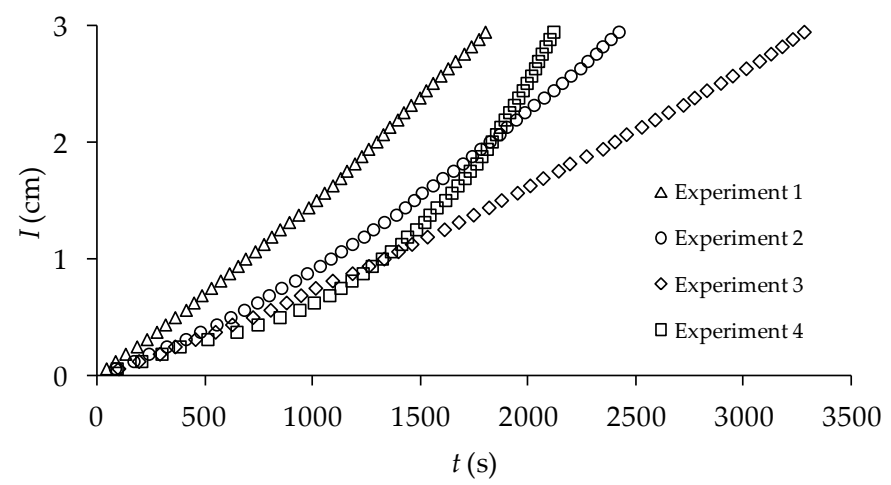

Figure 5. Dependence of cumulative infiltration on time measured at the V1 vineyard site (upper) and TF afforested site (lower).
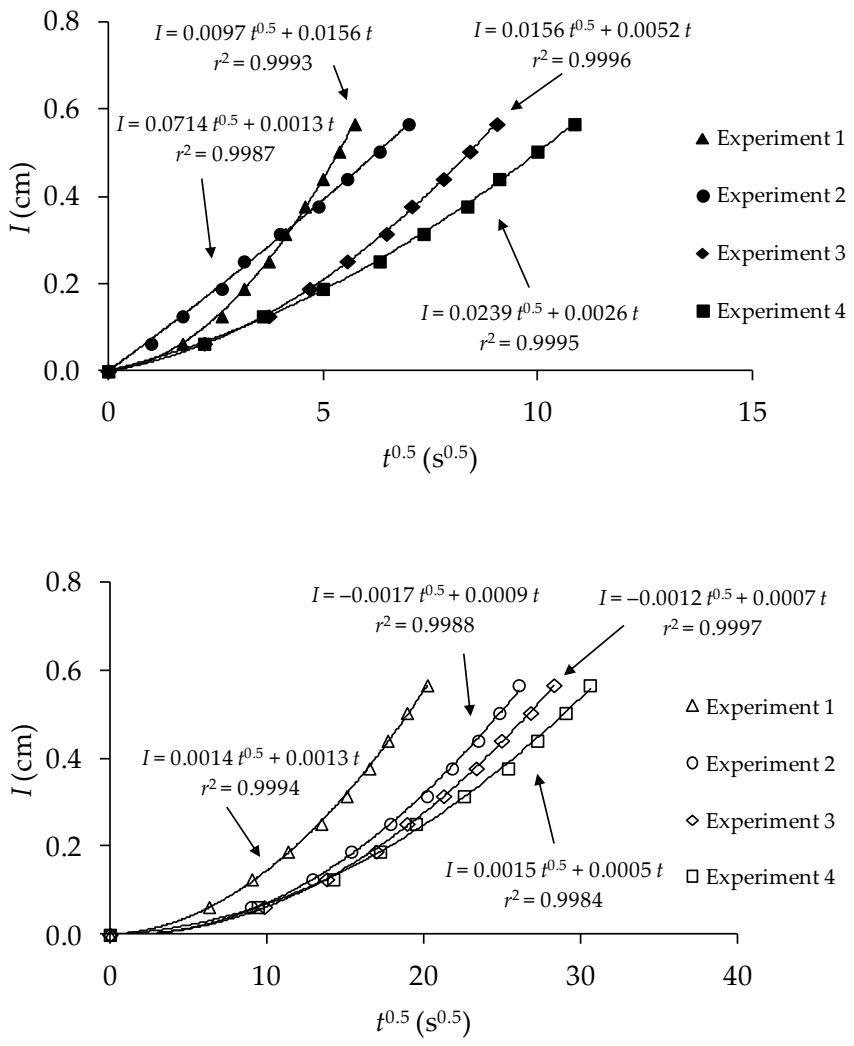

Figure 6. The early cumulative infiltration dependence on the square root of time, and the regression models (Equation (1)) fitted to four infiltration measurements at the V1 vineyard site (upper) and TF afforested site (lower). 


\section{Discussion}

\subsection{Impact of Land-Use on Soil Organic Carbon Content (SOC)}

The significantly increased SOC content observed after afforestation in the Little Carpathians are listed in Table 2. Kumm and Hessle [65] reported that natural vegetation recovery and afforestation resulted in increased soil organic matter from accumulated biomass and soil formation processes. In addition, Úbeda et al. [66] recorded that a lack of ploughing and vegetation recovery increased soil quality in agriculture terraces in the Capafonts in Catalonia on the Iberian Peninsula. These terraces had been initially abandoned and then subjected to prescribed fires.

Many authors focused their attention directly on the land-use effect upon SOC in soils [67,68]. Arable soils often suffer from a depletion of SOC [69]. However, the conversion of arable soils to pastures causes an increase in SOC $[43,44,46]$. A decrease in soil erosion and a slower rate of decomposition are responsible for this SOC increase [41,42,47]. The SOC decomposition rate is affected by various factors, such as organic matter composition, soil texture, structure, aeration, and moisture [70]. Changes in SOC content upon land-use changes are related to land-use intensity [71]. Schulze et al. [45] reported increasing average land-use intensities from forest to grasslands to cropland with an increasing harvested fraction of the net primary productivity $(12 \% \pm 3 \%, 29 \% \pm 8 \%$ and $47 \% \pm 15 \%$, respectively, for Europe). Thus, croplands leave a smaller SOC fraction than forests to build up and maintain SOC stocks [71].

\subsection{Impact of Land-Use on Soil Water Repellency}

Vineyard cultivation with consequent low organic matter content results in a low quantity of hydrophobic substances in the soil. However, there is a gradual increase in soil organic matter and hydrophobic substances when agricultural soils are transformed into forest or grasslands. Figures 2 and 3, as well as Table 2, show that the dependence of soil water repellency on soil organic matter content is expressed in a WDPT decline along with an SOC decrease in cultivated vineyard soils. This is supported in Seaton et al. [72], and many authors report the close association between organic matter content and soil water repellency [48-51,73-75].

In addition, Capriel [76] concluded that tillage depletes $\mathrm{C}-\mathrm{H}$ aliphatic units and, implicitly, soil organic matter hydrophobicity, and cultivation therefore results in decreased SOC and less water repellency. Franco et al. [77] then observed reduced water repellency in soils which had long been bare, without vegetation and plant residue supply, and Schnabel et al. [78] recorded a strong negative relationship between soil water repellency and the percentage of soil without plant cover.

In contrast, Doerr et al. [54] reported that some authors have noted only small or insignificant correlation between soil organic matter and soil water repellency [79,80]. Doerr et al. [54] further considered that even a small amount of hydrophobic substances can cause strong soil water repellency, and other authors ascribe the crucial development of water repellency to organic matter quality rather than quantity [81,82]. Despite these conflicting reports, it can be assumed that an increase in carbon content from land-use change affects the physical processes of soil that depend on soil-water interactions, i.e., infiltration, surface runoff, and erosion.

Seaton et al. [72] further reported that arable systems had significantly lower water repellency than all other land-uses, and this was even lower than expected due to their higher $\mathrm{pH}$ and lower carbon content. Figure 3 shows that the TF afforested study site is also less water repellent than expected from its SOC content, and this may be due to the effect of its higher soil $\mathrm{pH}$ compared to other forest and afforested sites (Figure 2, Table 2). This soil pH effect on water repellency is further recorded by authors including Lebron et al. [83], Mirbabaei et al. [84], and Kořenková et al. [85], and it was also experimentally investigated by Amer et al. [86] and Diehl [87].

The reasons $\mathrm{pH}$ affects soil water repellency include the following. The most frequently mentioned influence is protonation and deprotonation of soil organic functional groups such as carboxylics. The protonated carboxyl groups are less hydrophilic than deprotonated groups and this provides 
an indirect relationship between soil water repellency and soil acidity. Seaton et al. [72] considered that the relationship between soil $\mathrm{pH}$ and water repellency was due to differences in the soil bacterial composition.

The accumulation of plant litter is important in forest soils because this supports microbial activity and the accumulation of soil hydrophobic substances. Therefore, the measured values of the original forests and those in the afforested vineyards indicate medium to extreme soil water repellency. In addition, Jex et al. [88] confirm that thick forest litter significantly increases water repellency. The combined thicker litter layer and dead herbaceous undergrowth create favorable moisture conditions for microscopic fungi, and their hyphae support water repellency in the soil surface. Seaton et al. [72], also acknowledge the effect of microbial composition on soil water repellency in their ecological theory. This states that soil water repellency is an ecosystem response to a stressful environment, as a means of protecting microbes and ensuring better resource allocation with plants.

Agricultural land management can also promote changes in soil water repellency. Alternative management to tillage and herbicides such as catch crops, straw mulches, chipped pruned branches, manure, and compost addition to the soils contributes to an increase in soil organic matter and then in the soil water repellency, although reducing the soil losses [89]. A study by González-Peñaloza et al. [90] showed how the time since organic farming management in citrus plantation is the key to understanding the changes in soil water repellency and soil infiltration characteristics.

Governmental agencies are promoting the enhancement of soil organic matter in order to achieve sustainable soil management due to the land degradation suffered by vineyards [91,92] as a consequence of high erosion rates, which have led to a non-sustainable situation [93]. Our research provides information about the risk of increasing soil water repellency and causing a reduction in the soil infiltration rates as a consequence of those practices.

\subsection{Infiltration}

The infiltration rate decreases over time in wettable soils (Figure 4), which can be related to the sorption of water into wettable capillary pores [94], whereas the infiltration rate increases in non-wettable soils, as reported by a number of authors [94-97]. Researchers attribute the gradual increase in infiltration rate to the water repellent properties of the soil $[56,95,98,99]$. Similar experiments to ours, and in similar conditions, were performed by Orfánus et al. [100]. Their Decagon mini-disk infiltrometer-aided experiment recorded a significant decrease in hydraulic conductivity at $h=-2 \mathrm{~cm}$ in their water repellent sandy soils. The convex curves for water repellent soils are clearly apparent in the cumulative infiltration vs. time graphs (Figure 5), and concave curves are restricted to wettable soils [96].

Researchers have offered the following hypotheses for why the rate of infiltration increases in water repellent soils:

- $\quad$ the gradual decrease in soil water repellency with increasing depth [98];

- the dissolution of organic matter from soil in infiltrating water, which reduces water surface tension and therefore also reduces the contact angle [98];

- the dynamic change (decrease) of contact angles in bulk media [94];

- $\quad$ the dynamic change (increase) in the wettable fraction of the soil [101];

- $\quad$ the build-up of local pressures in the presence of internal ponding $[56,95]$.

Additional research results can be found in Bughici and Wallach [102], who recently employed the sessile drop test to establish the kinetics of the contact angle decrease over time, and in Beatty and Smith [101], who noted that the rate of change in soil wettability and the rate of change in soil wettable fraction are primary drivers of water flow when the contact angle changes substantially over time. Although the kinetics of these changes is important in determining the course of infiltration in water repellent soils, it is apparent that all of the above effects can contribute to the increased infiltration rate over time. 
Moreover, although infiltration theory indicates that the negative $C_{1}$ parameter values in the lower diagram in Figure 6 are physically impossible, similar negative values were reported by Beatty and Smith [101]. It is therefore most likely that the contact angle decreases with time, and that the decrease in water repellency during infiltration is responsible for the negative $C_{1}$ values.

Doerr et al. [99] consider that a significant reduction in the rate of water infiltration to the soil is one of the negative effects of soil water repellency, regardless of the mechanisms involved in the infiltration process. The reduced infiltration rate is most pronounced in the initial stages, and this causes a high susceptibility of water repellent soils to the formation of surface runoff (Hortonian flow). There is then less rainwater retention in catchments during heavy rains and significant intensification of erosion processes.

\subsection{Implications}

Grape production has long been considered an aggressive crop for soils because of the essential repetitive tillage that results in loss of vegetation cover and soil organic matter, and soil erosion. Thus, a millennia-old vineyard crop produces degraded soils. Rodrigo-Comino et al. [93] add that these negative effects confirm the current unsustainable vineyard management. Researchers are now investigating alternative management practices to reduce soil losses and soil degradation. These include the use of straw mulches [103], cover crops [104], manure [105], service crops [106], and organic farming [107]. These nature-based solutions should also enhance ecosystem services [108].

Our research established that vineyard abandonment transforms the soil into a body enriched in organic matter and plant cover, and this then induces a decrease in $\mathrm{pH}$ and a lower infiltration rate due to the impact of water repellency. Zhang et al. [109] consider that abandonment results in decreased infiltration rates on the millimeter (matrix) scale, and increased water repellency could force macropore flow into the deeper soil layers, where the extra water will help vegetation recovery. Alagna et al. [110] also reported low infiltration rates in Eastern Iberian Peninsula vineyards, whereas other researchers have demonstrated that forest soils are stable, with high infiltration rates [111].

\section{Conclusions}

This study in the wine-growing region of the Little Carpathians mountain range established significant differences between soils in cultivated vineyards, afforested vineyards, and forest areas.

The slightly acidic-to-alkaline vineyard soils with low organic carbon content changed to acidic soils with higher organic carbon content following afforestation. The differences in soil $\mathrm{pH}$ and organic carbon content are responsible for the significantly different hydrological properties in the vineyard and forest soils. In particular, the susceptibility to soil water repellency is greater in the forest and afforested soils. Although vineyard soils were wettable in all research sites, the forest and afforested soils were strongly to extremely water repellent, dependent on organic carbon content. The only exception to this is the transitional afforested soil, which is less water repellent than expected because of higher soil $\mathrm{pH}$.

In conclusion, the difference in soil wettability or repellency has a major effect on infiltration processes. The infiltration rate under near-saturated conditions was significantly lower in the afforested soil than in the vineyard. However, water repellency causes a gradual increase in the infiltration rate over time, and this contrasts sharply with wettable soil in which the infiltration rate decreases with time. Water repellency also causes the physically impossible negative sorptivity values determined in afforested soil.

Finally, our research demonstrates that vineyard abandonment promotes changes in the soil system, which induce restoration of original soil properties under forest management, and this results in increased water repellency and reduced soil matrix infiltration rates.

Author Contributions: Conceptualization, P.D., A.C.; formal analysis, A.H., P.D., A.C., and J.K.; methodology, P.D., A.C., and J.K.; writing-review and editing, A.H., P.D., A.C., and J.K.; funding acquisition, P.D. and J.K. All authors have read and agreed to the published version of the manuscript. 
Funding: This research was funded by the Slovak Scientific Grant Agency VEGA projects 1/0712/20, 2/0118/18 and 2/0096/19.

Conflicts of Interest: The authors declare no conflict of interest.

\section{References}

1. Rodrigo-Comino, J.; Senciales, J.M.; Cerdà, A.; Brevik, E.C. The multidisciplinary origin of soil geography: A review. Earth Sci. Rev. 2018, 177, 114-123. [CrossRef]

2. Keesstra, S.D.; Bouma, J.; Wallinga, J.; Tittonell, P.; Smith, P.; Cerdà, A.; Montanarella, L.; Quinton, J.N.; Pachepsky, Y.; van der Putten, W.H.; et al. The significance of soils and soil science towards realization of the United Nations Sustainable Development Goals. Soil 2016, 2, 111-128. [CrossRef]

3. Visser, S.; Keesstra, S.; Maas, G.; De Cleen, M. Soil as a basis to create enabling conditions for transitions towards sustainable land management as a key to achieve the SDGs by 2030. Sustainability 2019, 11, 6792. [CrossRef]

4. Keesstra, S.; Mol, G.; de Leeuw, J.; Okx, J.; de Cleen, M.; Visser, S. Soil-related sustainable development goals: Four concepts to make land degradation neutrality and restoration work. Land 2018, 7, 133. [CrossRef]

5. Ben-Salem, N.; Álvarez, S.; López-Vicente, M. Soil and water conservation in rainfed vineyards with common sainfoin and spontaneous vegetation under different ground conditions. Water 2018, 10, 1058. [CrossRef]

6. Novara, A.; Pulido, M.; Rodrigo-Comino, J.; Di Prima, S.; Smith, P.; Gristina, L.; Gimenez-Morera, A.; Terol, E.; Salesa, D.; Keesstra, S. Long-term organic farming on a citrus plantation results in soil organic matter recovery. Cuad. Investig. Geogr. 2019, 45, 271-286. [CrossRef]

7. Yang, S.; Sheng, D.; Adamowski, J.; Gong, Y.; Zhang, J.; Cao, J. Effect of land use change on soil carbon storage over the last 40 years in the Shi Yang River Basin, China. Land 2018, 7, 11. [CrossRef]

8. Keshavarzi, A.; Kumar, V.; Bottega, E.L.; Rodrigo-Comino, J. Determining land management zones using pedo-geomorphological factors in potential degraded regions to achieve land degradation neutrality. Land 2019, 8, 92. [CrossRef]

9. Kairis, O.; Dimitriou, V.; Aratzioglou, C.; Gasparatos, D.; Yassoglou, N.; Kosmas, C.; Moustakas, N. A comparative analysis of a detailed and semi-detailed soil mapping for sustainable land management using conventional and currently applied methodologies in Greece. Land 2020, 9, 154. [CrossRef]

10. Briassoulis, H. Combating land degradation and desertification: The land-use planning quandary. Land 2019, 8, 27. [CrossRef]

11. Twisa, S.; Buchroithner, M.F. Land-use and land-cover (LULC) change detection in Wami River Basin, Tanzania. Land 2019, 8, 136. [CrossRef]

12. Fernández-Nogueira, D.; Corbelle-Rico, E. Determinants of land use/cover change in the Iberian Peninsula (1990-2012) at municipal level. Land 2020, 9, 5. [CrossRef]

13. Ramankutty, N.; Foley, J.A. Estimating historical changes in global land cover: Croplands from 1700 to 1992. Glob. Biogeochem. Cycle 1999, 13, 997-1027. [CrossRef]

14. Achard, F.; Eva, H.D.; Stibig, H.J.; Mayaux, P.; Gallego, J.; Richards, T.; Maingreau, J.P. Determination of deforestation rates in the world's humid tropical forests. Science 2002, 297, 999-1002. [CrossRef]

15. Chowdhury, R.R.; Turner II, B.L. Reconciling agency and structure in empirical analysis: Smallholder land use in southern Yucatán. Ann. Assoc. Am. Geogr. 2006, 96, 302-322. [CrossRef]

16. Pan, W.; Carr, D.; Barbieri, A.; Bilsborrow, R.; Suchindran, C. Forest clearing in the Equadorian Amazon: A study of patterns over space and time. Popul. Res. Policy Rev. 2007, 26, 635-659. [CrossRef] [PubMed]

17. Häring, V.; Fischer, H.; Stahr, K. Erosion of bulk soil and soil organic carbon after land use change in northwest Vietnam. Catena 2014, 122, 111-119. [CrossRef]

18. Cramer, V.A.; Hobbs, R.J.; Standish, R.J. What's new about old fields? Land abandonment and ecosystem assembly. Trends Ecol. Evol. 2008, 23, 104-112. [CrossRef]

19. Prishchepov, A.V.; Radeloff, V.C.; Baumann, M.; Kuemmerle, T.; Müller, D. Effects of institutional changes on land use: Agricultural land abandonment during the transition from state-command to market-driven economies in post-Soviet Eastern Europe. Environ. Res. Lett. 2012, 7, 024021. [CrossRef]

20. Dlapa, P.; Hriník, D.; Hrabovský, A.; Šimkovic, I.; Žarnovičan, H.; Sekucia, F.; Kollár, J. The Impact of land-use on the hierarchical pore size distribution and water retention properties in loamy soils. Water 2020, 12, 339. [CrossRef] 
21. Bhawana, K.C.; Race, D. Outmigration and land-use change: A case study from the middle hills of Nepal. Land 2019, 9, 1-19.

22. Kolecka, N.; Kozak, J. Wall-to-wall parcel-level mapping of agricultural land abandonment in the Polish Carpathians. Land 2019, 8, 129. [CrossRef]

23. Cerdà, A.; Ackermann, O.; Terol, E.; Rodrigo-Comino, J. Impact of farmland abandonment on water resources and soil conservation in citrus plantations in eastern Spain. Water 2019, 11, 824. [CrossRef]

24. Hewelke, E. Influence of abandoning agricultural land use on hydrophysical properties of sandy soil. Water 2019, 11, 525. [CrossRef]

25. Wang, R.; Dong, Z.; Zhou, Z.; Wang, P. Temporal variation in preferential water flow during natural vegetation restoration on abandoned farmland in the Loess Plateau of China. Land 2019, 8, 186. [CrossRef]

26. Cerdà, A.; Rodrigo-Comino, J.; Novara, A.; Brevik, E.C.; Vaezi, A.R.; Pulido, M.; Gimenez-Morera, A.; Keesstra, S.D. Long-term impact of rainfed agricultural land abandonment on soil erosion in the Western Mediterranean basin. Prog. Phys. Geogr. 2018, 42, 202-219. [CrossRef]

27. Nadal-Romero, E.; Khorchani, M.; Lasanta, T.; García-Ruiz, J.M. Runoff and solute outputs under different land uses: Long-term results from a mediterranean mountain experimental station. Water 2019, 11, 976. [CrossRef]

28. Lasanta, T.; Nadal-Romero, E.; García-Ruiz, J.M. Clearing shrubland as a strategy to encourage extensive livestock farming in the Mediterranean mountains. Cuad. Investig. Geogr. 2019, 45, 487-513. [CrossRef]

29. Fernandez-Ales, R.; Martin, A.; Ortega, F.; Ales, E. Recent changes in landscape structure and function in a Mediterranean region of SW Spain (1950-1984). Landscape Ecol. 1992, 7, 3-18. [CrossRef]

30. García-Ruiz, J.M.; Nadal-Romero, E.; Lana-Renault, N.; Beguería, S. Erosion in Mediterranean landscapes: Changes and future challenges. Geomorphology 2013, 198, 20-36. [CrossRef]

31. Cerdà, A.; Jurgensen, M.F.; Bodi, M.B. Effects of ants on water and soil losses from organically-managed citrus orchards in eastern Spain. Biologia 2009, 64, 527-531. [CrossRef]

32. Keesstra, S.D. Impact of natural reforestation on floodplain sedimentation in the Dragonja basin, SW Slovenia. Earth Surf. Proc. Land. 2007, 32, 49-65. [CrossRef]

33. Ke, H.; Li, P.; Li, Z.; Shi, P.; Hou, J. Soil water movement changes associated with revegetation on the Loess Plateau of China. Water 2019, 11, 731. [CrossRef]

34. Yu, P.; Tang, X.; Liu, S.; Liu, W.; Zhang, A. Short term effects of revegetation on labile carbon and available nutrients of sodic soils in northeast China. Land 2020, 9, 10. [CrossRef]

35. Keesstra, S.D.; Bruijnzeel, L.A.; Van Huissteden, J. Meso-scale catchment sediment budgets: Combining field surveys and modeling in the Dragonja catchment, southwest Slovenia. Earth Surf. Proc. Land. 2009, 34, 1547-1561. [CrossRef]

36. Cammeraat, E.L.; Cerdà, A.; Imeson, A.C. Ecohydrological adaptation of soils following land abandonment in a semi-arid environment. Ecohydrology 2010, 3, 421-430. [CrossRef]

37. Cerdà, A.; Borja, M.E.L.; Úbeda, X.; Martínez-Murillo, J.F.; Keesstra, S. Pinus halepensis M. versus Quercus ilex subsp. Rotundifolia, L. runoff and soil erosion at pedon scale under natural rainfall in Eastern Spain three decades after a forest fire. For. Ecol. Manag. 2017, 400, 447-456.

38. Szilassi, P.; Jordan, G.; Van Rompaey, A.; Csillag, G. Impacts of historical land use changes on erosion and agricultural soil properties in the Kali Basin at Lake Balaton, Hungary. Catena 2006, 68, 96-108. [CrossRef]

39. Malherbe, H.; Pauleit, S.; Lorz, C. Mapping the loss of ecosystem services in a region under intensive land use along the southern coast of South Africa. Land 2019, 8, 51. [CrossRef]

40. Astier, M.; Orozco-Ramírez, Q.; Walker, R.; Galván-Miyoshi, Y.; González-Esquivel, C.; Simmons, C.S. Post-NAFTA changes in peasant land use-the case of the Pátzcuaro Lake watershed region in the Central-West México. Land 2020, 9, 75. [CrossRef]

41. Reeder, J.D.; Schuman, G.E. Influence of livestock grazing on C sequestration in semi-arid mixed-grass and short-grass rangelands. Environ. Pollut. 2002, 116, 457-463. [CrossRef]

42. Rasse, D.P.; Rumpel, C.; Dignac, M.F. Is soil carbon mostly root carbon? Mechanisms for a specific stabilisation. Plant Soil 2005, 269, 341-356. [CrossRef]

43. Young, R.R.; Wilson, B.; Harden, S.; Bernardi, A. Accumulation of soil carbon under zero tillage cropping and perennial vegetation on the Liverpool Plains, eastern Australia. Aust. J. Soil Res. 2009, 47, 273-285. [CrossRef] 
44. Luo, Z.; Wang, E.; Sun, O.J. Soil carbon change and its responses to agricultural practices in Australian agro-ecosystems: A review and synthesis. Geoderma 2010, 155, 211-223. [CrossRef]

45. Schulze, E.D.; Ciais, P.; Luyssaert, S.; Schrumpf, M.; Janssens, I.A.; Thiruchittampalam, B.; Theloke, J.; Saurat, M.; Bringezu, S.; Lelieveld, J.; et al. The European carbon balance. Part 4: Integration of carbon and other trace-gas fluxes. Glob. Change Biol. 2010, 16, 1451-1469. [CrossRef]

46. Badgery, W.B.; Simmons, A.T.; Murphy, B.M.; Rawson, A.; Andersson, K.O.; Lonergan, V.E.; van de Ven, R. Relationship between environmental and land-use variables on soil carbon levels at the regional scale in central New South Wales, Australia. Soil Res. 2013, 51, 645-656. [CrossRef]

47. Eyles, A.; Coghlan, G.; Hardie, M.; Hovenden, M.; Bridle, K. Soil carbon sequestration in cool temperate dryland pastures: Mechanisms and management options. Soil Res. 2015, 53, 349-365. [CrossRef]

48. Berglund, K.; Persson, L. Water repellence of cultivated organic soils. Acta Agr. Scand. Sect. B Soil Plant Sci. 1996, 46, 145-152. [CrossRef]

49. McKissock, I.; Gilkes, R.J.; Harper, R.J.; Carter, D.J. Relationships of water repellency to soil properties for different spatial scales of study. Aust. J. Soil Res. 1998, 36, 495-507. [CrossRef]

50. Varela, M.E.; Benito, E.; de Blas, E. Impact of wildfires on surface water repellency in soils of northwest Spain. Hydrol. Process. 2005, 19, 3649-3657. [CrossRef]

51. Kořenková, L.; Šimkovic, I.; Dlapa, P.; Urík, M. Statistical assessment of relationship between water repellency and selected properties of forest topsoil in the White Carpathian Mts. Carpath. J. Earth Environ. Sci. 2016, 11, 405-414.

52. Cerdà, A.; Doerr, S.H. Soil wettability, runoff and erodibility of major dry-Mediterranean land use types on calcareous soils. Hydrol. Process. 2007, 21, 2325-2336. [CrossRef]

53. DeBano, L.F. The role of fire and soil heating on water repellency in wildland environments: A review. J. Hydrol. 2000, 231-232, 195-206. [CrossRef]

54. Doerr, S.H.; Shakesby, R.A.; Walsh, R.P.D. Soil water repellency: Its causes, characteristics and hydro-geomorphological significance. Earth Sci. Rev. 2000, 51, 33-65. [CrossRef]

55. Wallis, M.G.; Scotter, D.R.; Horne, D.J. An evaluation of the intrinsic sorptivity water repellency index on a range of New Zealand soils. Aust. J. Soil Res. 1991, 29, 353-362. [CrossRef]

56. Feng, G.L.; Letey, J.; Wu, L. Water ponding depths affect temporal infiltration rates in a water repellent sand. Soil Sci. Soc. Am. J. 2001, 65, 315-320. [CrossRef]

57. Bauters, T.W.J.; DiCarlo, D.A.; Steenhuis, T.S.; Parlange, J.Y. Preferential flow in water-repellent sands. Soil Sci. Soc. Am. J. 1998, 62, 1185-1190. [CrossRef]

58. Rye, C.F.; Smettem, K.R.J. The effect of water repellent soil surface layers on preferential flow and bare soil evaporation. Geoderma 2017, 289, 142-149. [CrossRef]

59. International Union of Soil Sciences (IUSS) Working Group WRB. World Reference Base for Soil Resources 2014, International Soil Classification System for Naming Soils and Creating Legends for Soil Maps Update 2015; World Soil Resources Reports No. 106; International Union of Soil Sciences (IUSS): Vienna, Austria, 2015; p. 192.

60. Št'astný, P.; Niepelová, E.; Mello, M. Mean annual air temperature. In Landscape Atlas of the Slovak Republic, 1st ed.; Miklós, L., Hrnčiarová, T., Eds.; Ministry of Environment of the Slovak Republic: Bratislava, Slovakia; Slovak Environmental Agency: Banská Bystrica, Slovakia, 2002; p. 99.

61. Lapin, M.; Faško, P.; Melo, M.; Št'astný, P.; Tomlain, J. Climatic regions. In Landscape Atlas of the Slovak Republic, 1st ed.; Miklós, L., Hrnčiarová, T., Eds.; Ministry of Environment of the Slovak Republic: Bratislava, Slovakia; Slovak Environmental Agency: Banská Bystrica, Slovakia, 2002; p. 95.

62. Gee, G.W.; Bauder, J.W. Particle-Size analysis. In Methods of Soil Analysis, Part 1-Physical and Mineralogical Methods, 2nd ed.; Klute, A., Ed.; Agronomy Series 9; American Society of Agronomy: Madison, WI, USA; Soil Science Society of America: Madison, WI, USA, 1986; pp. 383-411.

63. Nelson, D.W.; Sommers, L.E. Total carbon, organic carbon, and organic matter. In Methods of Soil Analysis Part 3-Chemical Methods; Sparks, D.L., Page, A.L., Helmke, P.A., Loeppert, R.H., Soltanpour, P.N., Tabatabai, M.A., Johnston, C.T., Sumner, M.E., Eds.; Soil Science Society of America: Madison, WI, USA; American Society of Agronomy: Madison, WI, USA, 1996; pp. 961-1010.

64. Newville, M.; Otten, R.; Nelson, A.; Ingargiola, A.; Stensitzki, T.; Allan, D.; Fox, A.; Carter, F.; Michal; Pustakhod, D. lmfit/lmfit-py 1.0.0. 2019. Available online: https://zenodo.org/record/3588521 (accessed on 27 December 2019). 
65. Kumm, K.I.; Hessle, A. Economic comparison between pasture-based beef production and afforestation of abandoned land in Swedish forest districts. Land 2020, 9, 42. [CrossRef]

66. Úbeda, X.; Alcañiz, M.; Borges, G.; Outeiro, L.; Francos, M. Soil Quality of abandoned agricultural terraces managed with prescribed fires and livestock in the municipality of Capafonts, Catalonia, Spain (2000-2017). Agronomy 2019, 9, 340. [CrossRef]

67. Ding, L.; Wang, P.; Zhang, W.; Zhang, Y.; Li, S.; Wei, X.; Chen, X.; Zhang, Y.; Yang, F. Shrub encroachment shapes soil nutrient concentration, stoichiometry and carbon storage in an abandoned subalpine Grassland. Sustainability 2019, 11, 1732. [CrossRef]

68. Song, M.; Peng, W.; Du, H.; Xu, Q. Responses of soil and microbial C: N: P stoichiometry to vegetation succession in a Karst Region of Southwest China. Forests 2019, 10, 755. [CrossRef]

69. Bellamy, P.H.; Loveland, P.J.; Bradley, R.I.; Lark, R.M.; Kirk, G.J.D. Carbon losses from all soils across England and Wales 1978-2003. Nature 2005, 437, 245-248. [CrossRef] [PubMed]

70. Baritz, R.; Seufert, G.; Montanarella, L.; Van Ranst, E. Carbon concentrations and stocks in forest soils of Europe. Forest Ecol. Manag. 2010, 260, 262-277. [CrossRef]

71. Poeplau, C.; Don, A.; Vesterdal, L.; Leifeld, J.; Van Wesemael, B.; Schumacher, J.; Gensior, A. Temporal dynamics of soil organic carbon after land-use change in the temperate zone-Carbon response functions as a model approach. Glob. Change Biol. 2011, 17, 2415-2427. [CrossRef]

72. Seaton, F.; Jones, D.L.; Creer, S.; George, P.; Smart, S.M.; Lebron, I.; Barrett, G.; Emmett, B.; Robinson, D. Plant and soil communities are associated with the response of soil water repellency to environmental stress. Sci. Total Environ. 2019, 687, 929-938. [CrossRef]

73. Hermansen, C.; Moldrup, P.; Müller, K.; Jensen, P.W.; van den Dijssel, C.; Jeyakumar, P.; de Jonge, L.W. Organic carbon content controls the severity of water repellency and the critical moisture level across New Zealand pasture soils. Geoderma 2019, 338, 281-290. [CrossRef]

74. Mao, J.; Nierop, K.G.J.; Dekker, S.C.; Dekker, L.W.; Chen, B. Understanding the mechanisms of soil water repellency from nanoscale to ecosystem scale: A review. J. Soils Sediments 2019, 19, 171-185. [CrossRef]

75. Wang, J.-T.; Zheng, Y.-M.; Hu, H.-W.; Li, J.; Zhang, L.-M.; Chen, B.-D.; Chen, W.-P.; He, J.-Z. Coupling of soil prokaryotic diversity and plant diversity across latitudinal forest ecosystems. Sci. Rep. 2016, 6, 19561. [CrossRef]

76. Capriel, P. Hydrophobicity of organic matter in arable soils: Influence of management. Eur. J. Soil Sci. 1997, 48, 457-462. [CrossRef]

77. Franco, C.M.M.; Clarke, P.J.; Tate, M.E.; Oades, J.M. Hydrophobic properties and chemical characterisation of natural water repellent materials in Australian sands. J. Hydrol. 2000, 231-232, 47-58. [CrossRef]

78. Schnabel, S.; Pulido-Fernández, M.; Lavado-Contador, J.F. Soil water repellency in rangelands of Extremadura (Spain) and its relationship with land management. Catena 2013, 103, 53-61. [CrossRef]

79. Harper, R.J.; McKissock, I.; Gilkes, R.J.; Carter, D.J.; Blackwell, P.S. A multivariate framework for interpreting the effects of soil properties, soil management and landuse on water repellency. J. Hydrol. 2000, 231-232, 371-383. [CrossRef]

80. Scott, D.F. Soil wettability in forested catchments in South Africa; as measured by different methods and as affected by vegetation cover and soil characteristics. J. Hydrol. 2000, 231-232, 87-104. [CrossRef]

81. DeBano, L.F.; Mann, L.D.; Hamilton, D.A. Translocation of hydrophobic substances into soil by burning organic litter. Soil Sci. Soc. Am. Pro. 1970, 34, 130-133. [CrossRef]

82. Wallis, M.G.; Horne, D.J. Soil water repellency. Adv. Soil S 1992, 20, 91-146.

83. Lebron, I.; Robinson, D.A.; Oatham, M.; Wuddivira, M.N. Soil water repellency and pH soil change under tropical pine plantations compared with native tropical forest. J. Hydrol. 2012, 414-415, 194-200. [CrossRef]

84. Mirbabaei, S.M.; Shahrestani, M.S.; Zolfaghari, A.; Abkenar, K.T. Relationship between soil water repellency and some of soil properties in northern Iran. Catena 2013, 108, 26-34. [CrossRef]

85. Kořenková, L.; Šimkovic, I.; Dlapa, P.; Juráni, B.; Matúš, P. Identifying the origin of soil water repellency at regional level using multiple soil characteristics: The White Carpathians and Myjavska Pahorkatina Upland case study. Soil Water Res. 2015, 10, 78-89. [CrossRef]

86. Amer, A.; Schaumann, G.E.; Diehl, D. The effect of $\mathrm{pH}$ modification on wetting kinetics of a naturally water-repellent coniferous forest soil. Eur. J. Soil Sci. 2017, 68, 317-326. [CrossRef]

87. Diehl, D. Soil water repellency: Dynamics of heterogeneous surfaces. Colloids Surf. A Physicochem. Eng. Asp. 2013, 432, 8-18. [CrossRef] 
88. Jex, G.W.; Bleakley, B.H.; Hubbell, D.H.; Munro, L.L. High humidity-induced increase in water repellency in some sandy soils. Soil Sci. Soc. Am. J. 1985, 49, 1177-1182. [CrossRef]

89. Cerdà, A.; Rodrigo-Comino, J.; Yakupoğlu, T.; Dindaroğlu, T.; Terol, E.; Mora-Navarro, G.; Vaverková, M.D. Tillage versus no-tillage. Soil properties and hydrology in an organic persimmon farm in Eastern Iberian Peninsula. Water 2020, 12, 1539. [CrossRef]

90. González-Peñaloza, F.A.; Cerdà, A.; Zavala, L.M.; Jordán, A.; Giménez-Morera, A.; Arcenegui, V. Do conservative agriculture practices increase soil water repellency? A case study in citrus-cropped soils. Soil Till. Res. 2013, 124, 233-239. [CrossRef]

91. Baiamonte, G.; Minacapilli, M.; Novara, A.; Gristina, L. Time scale effects and interactions of rainfall erosivity and cover management factors on vineyard soil loss erosion in the semi-arid area of southern Sicily. Water 2019, 11, 978. [CrossRef]

92. Mirás-Avalos, J.M.; Ramírez-Cuesta, J.M.; Fandiño, M.; Cancela, J.J.; Intrigliolo, D.S. Agronomic practices for reducing soil erosion in hillside vineyards under Atlantic climatic conditions (Galicia, Spain). Soil Syst. 2020, 4, 19. [CrossRef]

93. Rodrigo-Comino, J.; Keesstra, S.; Cerdà, A. Soil erosion as an environmental concern in vineyards: The case study of Celler del Roure, Eastern Spain, by means of rainfall simulation experiments. Beverages 2018, 4, 31. [CrossRef]

94. Beatty, S.M.; Smith, J.E. Dynamic soil water repellency and infiltration in post-wildfire soils. Geoderma 2013, 192, 160-172. [CrossRef]

95. Clothier, B.E.; Vogeler, I.; Magesan, G.N. The breakdown of water repellency and solute transport through a hydrophobic soil. J. Hydrol. 2000, 231-232, 255-264. [CrossRef]

96. Wallach, R.; Graber, E.R. Infiltration into effluent irrigation-induced repellent soils and the dependence of repellency on ambient relative humidity. Hydrol. Process. 2007, 21, 2346-2355. [CrossRef]

97. Fischer, T.; Yair, A.; Veste, M.; Geppert, H. Hydraulic properties of biological soil crusts on sand dunes studied by 13C-CP/MAS-NMR: A comparison between an arid and a temperate site. Catena 2013, 110, 155-160. [CrossRef]

98. Arye, G.; Tarchitzky, J.; Chen, Y. Treated wastewater effects on water repellency and soil hydraulic properties of soil aquifer treatment infiltration basins. J. Hydrol. 2011, 397, 136-145. [CrossRef]

99. Doerr, S.H.; Shakesby, R.A.; MacDonald, L.H. Soil water repellency: A key factor in post-fire erosion. In Fire Effects on Soils and Restoration Strategies; Cerda, A., Robichaud, P., Eds.; Science Publishers Inc.: Enfield, NH, USA, 2009; pp. 197-224.

100. Orfánus, T.; Dlapa, P.; Fodor, N.; Rajkai, K.; Sándor, R.; Nováková, K. How severe and subcritical water repellency determines the seasonal infiltration in natural and cultivated sandy soils. Soil Till. Res. 2014, 135, 49-59. [CrossRef]

101. Beatty, S.M.; Smith, J.E. Infiltration of water and ethanol solutions in water repellent post wildfire soils. J. Hydrol. 2014, 514, 233-248. [CrossRef]

102. Bughici, T.; Wallach, R. Formation of soil-water repellency in olive orchards and its influence on infiltration pattern. Geoderma 2016, 262, 1-11. [CrossRef]

103. Cerdà, A.; Rodrigo-Comino, J.; Giménez-Morera, A.; Keesstra, S.D. An economic, perception and biophysical approach to the use of oat straw as mulch in Mediterranean rainfed agriculture land. Ecol. Eng. 2017, 108, 162-171. [CrossRef]

104. Novara, A.; Catania, V.; Tolone, M.; Gristina, L.; Laudicina, V.A.; Quatrini, P. Cover crop impact on soil organic carbon, nitrogen dynamics and microbial diversity in a Mediterranean semiarid vineyard. Sustainability 2020, 12, 3256. [CrossRef]

105. Ramos, M.C.; Martínez-Casasnovas, J.A. Erosion rates and nutrient losses affected by composted cattle manure application in vineyard soils of NE Spain. Catena 2006, 68, 177-185. [CrossRef]

106. García, L.; Celette, F.; Gary, C.; Ripoche, A.; Valdés-Gómez, H.; Metay, A. Management of service crops for the provision of ecosystem services in vineyards: A review. Agr. Ecosyst. Environ. 2018, 251, 158-170. [CrossRef]

107. Puig-Montserrat, X.; Stefanescu, C.; Torre, I.; Palet, J.; Fàbregas, E.; Dantart, J.; Arrizabalaga, A.; Flaquer, C. Effects of organic and conventional crop management on vineyard biodiversity. Agr. Ecosyst. Environ. 2017, 243, 19-26. [CrossRef] 
108. Keesstra, S.; Nunes, J.; Novara, A.; Finger, D.; Avelar, D.; Kalantari, Z.; Cerdà, A. The superior effect of nature based solutions in land management for enhancing ecosystem services. Sci. Total Environ. 2018, 610, 997-1009. [CrossRef] [PubMed]

109. Zhang, Y.; Zhang, Z.; Ma, Z.; Chen, J.; Akbar, J.; Zhang, S.; Che, C.; Zhang, M.; Cerdà, A. A review of preferential water flow in soil science. Can. J. Soil Sci. 2018, 98, 604-618. [CrossRef]

110. Alagna, V.; Bagarello, V.; Di Prima, S.; Guaitoli, F.; Iovino, M.; Keesstra, S.; Cerdà, A. Using Beerkan experiments to estimate hydraulic conductivity of a crusted loamy soil in a Mediterranean vineyard. J. Hydrol. Hydromech. 2019, 67, 191-200. [CrossRef]

111. Alaoui, A.; Caduff, U.; Gerke, H.H.; Weingartner, R. Preferential flow effects on infiltration and runoff in grassland and forest soils. Vadose Zone J. 2011, 10, 367-377. [CrossRef]

(C) 2020 by the authors. Licensee MDPI, Basel, Switzerland. This article is an open access article distributed under the terms and conditions of the Creative Commons Attribution (CC BY) license (http://creativecommons.org/licenses/by/4.0/). 